\title{
State of the Field: What Can Political Ethnography Tell Us about Anti-Politics and Democratic Disaffection?
}

The twin shocks of Brexit and Donald Trump's electoral victory in 2016 have prompted widespread reflection on rising disaffection towards the political establishment (Inglehart and Norris, 2016). Of course, concern about 'democratic crisis' is not new (Crozier et al. 1974). There has been considerable scholarship in America (Pharr and Putnam 2000; Dalton 2004; Catterberg and Moreno 2006; Torcal and Montero 2006; Norris 2011), and Europe (Stoker 2006; Hay 2007; Flinders 2012; Papadopoulos 2013) dedicated to understanding the causes and consequences of these trends. This work shows that rising public disaffection, commonly expressed as cynicism, resentment and even hatred of democratic institutions and governing elites, feeds populist causes (e.g. Mudde 2007; Rooduijn et al. 2014) and erodes the capacity to govern (see Olsen 1969; Finifter 1970; Hetherington 2006; Hetherington and Thomas 2015). It suggests also that the legitimacy crisis is intensifying (see Clarke et al. 2016). Reflecting on the populist appeal to 'demystify’ politics, Mudde (2004, 557) suggests:

More and more citizens think they have a good understanding of what politicians do, and think they can do it better. While this does not necessarily mean that many people also actually want to do it better, by actively participating in various aspects of political life, it does mean that the relationship between the elites and the citizens has changed significantly, and possibly irrevocably, over the past decades.

This voter cynicism about 'the establishment' mirrors scholarly presumptions about myopic self-interest and calculating strategic action. Rational choice analysis and the 
new institutionalism constitute the theoretical mainstream (Goodin and Klingemann 1996: 20; Goodin 2009: 9; Rhodes 2017: 212-15). As a result, political scientists often model human behaviour in this way, especially the behaviour of the political elite. As a discipline, this stance should provide cause for concern. Either the political system is as bad as the increasingly disaffected public believes, in which case we should collectively be supporting attempts to 'drain the swamp'; or the way we do political science needs to change to allow us to tell different stories about the motivations, beliefs and practices of political actors.

Most of the vast literature directed towards understanding the causes of rising public disaffection towards democratic government, its institutions and actors, has focused on what Colin Hay (2007) calls the 'demand side' — that is, changes in society which influence the demands that citizens place on the political system. This work links shifts in public attitudes and behaviour with declining voter turnout, membership of political parties and increasingly negative views of the political elite. Surveys and quantitative analysis have provided the dominant methods. Examples include the analysis of political disengagement and political attitudes using data from the World Values Survey, European Values Survey, American National Election Studies, European Social Survey, British Social Attitudes Survey and British Election Study (for example, Norris 1999; Pharr and Putnam 2000; Dalton 2004; Catterberg and Moreno 2006; Torcal and Montero 2006; Clarke et al. 2016). Demand-side analyses also focus on how the public judge their politicians' conduct and performance, ascribing increased negativity to a combination of innate complexity, political selfinterest and unrealistic public expectations. 
While this work has delivered important insights, it does nothing to explore how elites are affected by or seek to combat these assumptions. It implicitly treats the 'supply side' as constant. Yet there have been major shifts in the nature and conduct of democratic politics linked to professionalization (e.g. Campbell and Cowley 2013; 2015), the changing profiles of legislatures (e.g. Allen and Cairney 2016), and so on (see Stoker and Hay 2016 for discussion). The primary methods of contemporary political science are less equipped to explore what drives the beliefs and practices of political elites - the 'supply side' - which has been credited widely with public disaffection with politics.

Greater methodological pluralism and ethnographic methods in particular have much to offer both 'demand' and 'supply' side explanations of democratic disaffection. For example, the recent publication of rich qualitative work based on ethnographic immersion is beginning to tease out subtleties and nuances of the dynamics underlying this new 'politics of resentment' (Cramer 2016) and emotional alienation (Hochschild 2016). But, we argue that these approaches are especially important for explain the 'supply side' of political practices such as 'professionalization'. In particular, we make the case for an increased use of ethnographic approaches that currently exist on the margins of political science research. Prevailing methods tell us little about how elites practice politics, including the everyday rituals and routines that constitute political life. Also, they reinforce the negative public perception of how politics works, and curtail the ability of political scientists to tell a compelling normative story about the meaning and purpose of democratic politics.

In this article, we argue for ethnography as an approach to understanding politics and government. We make three moves. First, we defend a broad approach to ethnography 
that encompasses more than deep immersion. Second, we build on the small literature that makes the case for political scientists doing ethnography (e.g. Fenno 1990; De Velo and Schatz 2009; Schatz 2009; Wedeen 2010). In doing so, we debunk common myths about the value of an ethnographic approach. Third, we review the small number of elite ethnographies from either side of the Atlantic to consider what they might tell us about the professionalization of politics (e.g. Fenno 1978; Gaddie 2005; Crewe 2005; 2015; Reheer 2006; Rhodes 2011; Corbett 2015). These studies focus on campaigning and governing practice. They provide a glimpse of the importance of both understanding governing elites and injecting such understandings into public debates about revitalising politics.

\section{Bridging the Gap: What Can Ethnographic Research Tell Us about Democratic Disaffection?}

Nearly three decades ago, Richard Fenno commented that 'not enough political scientists are presently engaged in observation' (1990, 128). Nothing has changed. A recent review by Kaposzewski et al. (2015: 234) concluded that 'political science has yet to embrace ethnography and participant observation wholeheartedly'. Indeed, there is a 'double absence: of politics in ethnographic literature and of ethnography in the study of politics' (Auyero and Joseph 2007: 2, emphasis in the original). At the heart of this absence lie key misconceptions about what ethnography is good for. We debunk these persistent myths. However, we need to start by defining what we are debunking.

What is ethnography? ${ }^{1}$ 
For Hammersley and Atkinson (2007: 2), 'ethnography does not have a standard, well-defined meaning'. Nonetheless, some words and phrases recur. The ethnographer studies people's everyday lives. Such fieldwork is unstructured. The aim is to recover the meaning of their actions by deep immersion, whether looking at a Congressional district or a government department. Historically, it meant going to another country, learning the language and studying the everyday lives of the inhabitants of a village, tribe, or whatever unit of social organisation had been selected. For the newcomer it was the only way to become a cultural anthropologist; 'you can't teach fieldwork, you have to do it'. For Wood (2006: 123), it is 'research based on personal interaction with research subjects in their own setting', not in the laboratory, the library or one's office. It is deep hanging out or intensive immersion in the everyday lives of other people in their local environment normally for a substantial period.

Of course, fieldwork has various pen names such as the 'thick descriptions' (Geertz 1973: chapter 1) and 'the extended case study' (Aronoff and Kubik (2013: 56-7). There are affinities with the case studies common in political science, which are also in-depth studies of a single unit or event. The method was criticised often for being idiographic and not fostering generalisations. Latterly, political scientists have devoted much effort to assimilating the case method to naturalism and its language of variables and hypothesis testing. For example, Wood analysed five case studies of peasant support for insurgent groups explicitly 'sacrificing ethnographic depth of analysis for analytical traction through comparison of cases that vary in the extent of mobilisation observed'. It was her way of overcoming 'the obstacles to making valid 
causal inferences based on field data' (Wood 2007: 132 and 142). So, case studies can be simply descriptions of specific subjects but political scientists are enjoined to use them to build theory, to test the validity of specific hypotheses, and to test theories by treating them as the equivalent of decisive experiments (see Eckstein 1975: 92-123; see also Yin 2014; Gerring 2007).

While ethnography has affinities with case studies and qualitative research common to mainstream political science, it is more commonly associated with an interpretive approach because it favours depth - complex specificity in context - not valid causal inference (see Bevir and Rhodes 2003; Lincoln and Guba 1985; Wolcott 1995). Anthropologists would not refer to their fieldwork site as a 'case study' because it is not a 'case' of anything until they withdraw from the field to analyse and write up their field notes. Indeed, interpretive ethnography is less concerned with generalisations than with raising new questions and 'shaking the bag'. The aim is edification - that is, finding 'new, better, more interesting, more fruitful ways of speaking about' politics and government (Rorty 1980: 360). Interpretive ethnography provides detailed studies of social and political dramas but it is not limited to the microscopic. As Geertz 1993: 23) suggests, 'small facts to speak to large issues' (see also Burawoy 1998: 5).

This division of labour, while common, is also misleading because the popular conception of ethnography as exclusively 'deep immersion' has been challenged. In sociology, ethnographers have long practiced 'partial immersion' (Delamont 2004: 206). In the anthropological 'culture wars' of the 1980s, the contributors to Clifford 
and Marcus (1984) denied deep hanging out's claim to ethnographic authority in representing other cultures. It was said to produce colonial, gendered and racist texts with a specious claim to objectivity. Their aim was to deconstruct all essential concepts such as 'culture', and all generalisations. So, we have:

'a trend towards the specification of discourses in ethnography: who speaks? who writes? when and where? with or to whom under what institutional or historical constraints? (Clifford 1984: 13)

The classic immersive study was challenged by 'hit-and-run ethnography' (Geertz 2001: chapter 5). We 'study through' by conducting 'yo-yo-research' in 'contact zones' and multi-local sites. 'Studying through' refers to following events such as making a policy through the 'webs and relations between actors, institutions and discourses across time and space' (Shore and Wright 1997: 14). 'Yo-Yo research' refers to both regular movement in and out of the field and to participant observation in many local sites (Wulff 2002; Marcus 1995). A 'contact zone' is the 'space', such as 'a museum, in which peoples geographically and historically separated come into contact with each other and establish ongoing relations', usually characterised by inequality and conflict (Clifford 1997: 6-7). Marcus (2007a) describes the current practices of ethnography as 'baroque' as even partial immersion becomes dispersed over several sites.

To be clear, we are not dismissing the value of an immersive approach to ethnography. Rather we raise this point to illustrate that there is a menu of ethnographic choices, and that some are more suited to studying elites than others. 
Elite ethnography is difficult and poses many challenges. We attempt to enter a closed and secretive world, a hidden world, occupied by people who are more powerful than the researcher. Observing governing elites at work is the preferred research method but we know from bitter experience that requests for such access can be denied. We have to find other ways of 'being there' (see also Nader 1972: 306-7).For example, focus groups can give access to a group of elite actors. We can observe them in action when observation is not possible at the workplace, especially when the relevant individuals are no longer in office. They are another way of 'being there' and sidestepping the problems of access and secrecy (see Rhodes and Tiernan 2014).

That said, the several ways of 'being there' are not stand-alone methods. Ideally, we would supplement each method with shadowing. Most important, the data generated by focus groups and other methods require an 'ethnographic sensibility' for interpreting the conversations (Agar and McDonald 1995; Schatz 2009). The various ethnographic methods suggested in Table 1 are still about recovering meaning and locating that meaning in its broader context. So, focus groups are an ethnographic method because ethnography is now a diverse set of practices linked not by a shared method - participant observation - but by a shared focus on the recovery of meaning the ethnographic sensibility (see also Katz 2009: 5).

Dichotomies mislead. They can become straitjackets. We do not see deep hanging out and hit-and-run fieldwork as mutually exclusive. We incline to Fox's (2004: 4) practical and pragmatic assessment of deep hanging out; it is a 'rather uneasy combination of involvement and detachment' but it 'is still the best method we have for exploring the complexities of human cultures, so it will have to do'. It may be the best method but it is not the only one. We prefer to talk of 'bricolage' - that is, 
constructing research from diverse methods and materials (Denzin and Lincoln 2011: 4; and Table 1 below) - and bringing an 'ethnographic sensibility' to bear on the data, however collected.

There is an elephant in our ethnographic room - how short can a fieldwork trip be and still count as ethnography? How long do you need to be there to tell a wink from a blink (Geertz 1973: 6-7)? Marcus (2007b) sees lengthy fieldwork stays as a 'variable component' in any research project. In our experience, there is no magic number for how long you should spend in the field. There is no magic number of interviews to conduct or documents to read (Corbett 2015; see also Small 2009). Most importantly, 'more' is manifestly not always 'better'. Indeed, more data exacerbates the problem of seeing the wood for the trees rather than leading to richer and deeper insights. 'More is better' is an impossible standard that can never be met. Our rule of thumb is to yo-yo in and out of field sites until you have stopped recording interesting data when it becomes repetitive and you think you can answer your research questions. It is a judgement by the researcher. There are no hard and fast rules. As Marcus (2007a) says, incompleteness is the norm.

In sum, our conception of ethnography is broad and eclectic (and for a more detailed account see Rhodes 2017: chapters 3-5). The ethnographer is a bricoleur with an ethnographic sensibility. We now bring this perspective to bear on conventional understandings of the field.

Myth 1: Ethnography is only for the exotic 
If ethnographic approaches are valued in political science, it is for their capacity to illuminate features of politics that mainstream approaches cannot penetrate. This belief has enabled ethnography to survive for studying exotic regions of the world that have unreliable datasets and unfamiliar political practices. As Shore and Nugent (2002: 11) comment, 'Anthropology, by definition, is the study of powerless "Others". Nader (1972: 289) was an early voice calling for anthropologists to "study up,' recognising that 'there is comparatively little field research on the middle class and very little-first hand work on the upper class'. When talking about political and governmental elites, little has changed in the intervening years, although we note some distinguished exceptions below. Indeed, most of the studies using ethnography in political science 'study down' with street level bureaucrats a favoured topic (see for example Maynard-Moody and Musheno. 2003).

Ethnography undeniably is useful for studying exotic settings and local politics. However, this is far from its only use. Over the last two decades or more, anthropology - the discipline that lays claim to 'owning' ethnography - has witnessed a shift away from making the exotic familiar, and towards making the familiar exotic. Indeed, much modern Anthropology focuses not on the distant village but on local settings of everyday life-factory floors, village halls, schools, university corridors (for a political science example see Pachirat 2011). The value of the ethnographic approach in such settings is that it can cast new light on what we think we already know.

Few settings are subject to as many implicit assumptions as political institutions in advanced liberal democracies. The public thinks they know who politicians are, what they do, and how they perform (Mudde 2004). Political scientists model and structure 
such institutions based on parsimonious assumptions about their behaviour. Yet, as we will show, the small but rich seam of ethnographic research on the actors at the heart of political institutions suggests that these presumptions are limiting if not misleading.

\section{Myth 2: Ethnographic data is unreliable}

This myth encompasses three main objections: that ethnography is a risky form of data collection; that it is impossible to generalize from ethnographic data; and that it does not produce causal explanations. We address each in turn.

The first objection is that doing ethnography is risky because it depends on rich data the researcher cannot guarantee before entering the field. We accept that the classic intensive participant-observation study remains the defining method but, as above, for the study of political and governmental elites, it may not be feasible. Are there other ways of 'being there'? Can we bring the ethnographic sensibility to bear on data collected by other means? Existing studies on the margins of political science show that there are many methods and sources that ethnographers can draw on to provide deep and novel insights into the beliefs and practices of political elites (see Table 1 for a summary). All give the researcher a sense of 'being there'. Deployed together, these methods can be used to triangulate claims, background stories and flesh out emergent themes.

\section{INSERT TABLE 1 ABOUT HERE}


The second objection is that it is not possible to deduce laws and predict outcomes from fieldwork; that is, it is not possible to generalize (found even in sympathetic accounts of 'narrative approaches' e. g. Laitin 2006: 27). The common error is to equate generalisation with the formal or statistical generalisation associated with the natural science model of research. We cannot formally generalise but we can still aspire to 'plausible conjecture'. We can make general statements that are plausible because they rest on good reasons and the reasons are good because they are inferred from relevant information (paraphrased from Boudon 1993). Plausible conjectures are to interpretive research what generalisations are to naturalist research. The aim is complex specificity in context, not formal generalisations (Schwartz-Shea and Yanow 2012: 46-49).

The third objection is that ethnographic approaches cannot produce a causal account of politics; that is, they describe and understand actions and practices, but they do not explain them. This myth persists despite rigorous and sophisticated refutation (Katz 2001; 2002). In fact, ethnography has a distinctive form of explanation, which Bevir (2006) refers to as 'narrative'. A narrative unpacks the disparate and contingent beliefs and practices of individuals through which they construct their world and identifies the recurrent patterns of actions and related beliefs. We explain actions and practices in narratives by identifying the set of reasons, conscious and unconscious, that led to the particular action. Interpretive ethnography is about explanation, not understanding, and narratives are the way interpretive ethnography explains actions and practices.

\section{Myth 3: Ethnography is uncritical}


There is a pervasive scepticism about ethnographic methods because they are said to blunt the capacity for critical analysis. The suspicion is that researchers dependent on elites for access will become uncritical apologists for their failings. This presumption is crude and inaccurate for two reasons.

First, concern about academic 'Stockholm Syndrome' is tempered once we appreciate that ethnography can and does entail the multiplicity of methods of data collection discussed above. Ethnographers can piece together their analysis without being dependent on individual elites over long periods. They can also use data from across these multiple, diverse sources to triangulate the claims that individuals make about their actions and their professed motivations. They can compare the data from 'practice, talk, and considered writing' and explore contradictions (Oakeshott 1996: $\mathrm{x})$.

Second, the stories that elites tell are not necessarily unreflexive or one-sided. This belief is not naive. Obviously many political actors will present themselves and their motivations in the best possible light. Yet what we know from existing studies of different sorts of political actors is that they are often fiercely critical of each other, and of democratic institutions and practices (e.g. Boswell and Corbett 2015). Taking their insights seriously can broaden and enrich our understanding of the problems that pervade elite institutions. It can ultimately sharpen our diagnosis of the drivers of democratic disaffection.

\section{Lessons from Elite Ethnography}


We have argued that ethnographic research can fill an important gap in the existing literature on public disaffection with governing elites, in the process debunking common myths about what this research entails. Now we illustrate the pay-off such research can deliver. To do so, we draw on pioneering ethnographic studies of elite political actors and politicians in particular. None explicitly engages with questions about public trust and governing elites. Therefore, we reinterpret this research for our purposes. In particular, we highlight how everyday dilemmas, derived from the time constraints, media and electoral pressures and limited resources of political life, shape the contemporary 'professionalization' of politics. Understanding these factors, often hidden in quantitative and 'standard' qualitative explanations, which explain why politicians act in a way that reproduces disaffection, enables a nuanced account of the professionalization of politicians. It acknowledges that politicians often act in ways that perpetuate negative images of politics, but cautions that the explanation for their actions lies in the fine-grained, often intractable, realities of political life.

\section{INSERT TABLE 2 ABOUT HERE}

\section{Lesson 1: Local politicians demonise national elites}

As we have seen, the presumption at the heart of rising disaffection is a sense that the political class is disconnected from everyday citizens (Mudde 2004). Mainstream political science largely supports popular ideas about the increasing homogeneity of professionalised party systems (see e.g. Hay 2007).

Insights from elite ethnography show that this 'disconnection' arises because of the norms embedded in political campaigning. The pioneering work of Fenno (1978; 
1990) sheds important light on campaigning. Fenno shadowed 18 members in the constituency for 2-3 days each over an 8-year period. He noted a tendency for politicians to engage in what he called a 'Home Style'. Far from conveying the sense that they were a 'machine politician' from a Beltway production line, politicians would go out of their way to cultivate and perform a home-grown approach and distant themselves from Washington. Trust is central to how politicians cultivate their 'Home Style' (see Fenno 1978, p. 55-57):

Trust is, however, a fragile relationship. It is not an overnight or a one-time thing. It is hard to win; and it must be constantly renewed and re-won. 'Trust,' said one member 'is a cumulative thing, a totality thing ... You do a little here and a little there.' ... That is what House members believe. And that is why they spend so much of their working time at home. Much of what I have observed in my travels can be explained as a continuous and continuing effort to win (for members) and to hold (for old members) the trust of supportive constituencies (Fenno 1978, p. 56).

Recent ethnographic studies by Gaddie's (2003) and Reheer (2006) extend these insights. Drawing together data drawn many sources using the multiple methods of contemporary ethnography - including observation but also interviews and the public record - Gaddie's key contribution is to focus on the ambition underpinning the pursuit of a career in politics. His analysis of campaigning reveals how professionalised politics has become since Fenno. He identifies twin drivers for this phenomenon. First, technological change has allowed candidates to produce cheaper 
and better media. Second, declining civic participation has meant candidates can no longer rely on an army of volunteers in the constituency.

Both sets of insights have implications for explaining the professionalization of political campaigning. Political parties engaged in competitive elections have a set of norms that specify what it takes to gain the support necessary to be elected. They emphasise local identity and political ambition to create trust, and using technologies to bridge a falling activist base. These campaigning practices are embedded in the culture of political parties, and are part of the trend towards professionalization. This insight suggests the drivers of professionalized campaigning lie not just in the national party system but also in the micro-level incentives and dilemmas local candidates face, which push them towards this professionalized approach.

In addition, these studies suggest that political candidates themselves may play a central role in reproducing negative stories about the 'Beltway Elite'. In their efforts to distance themselves from these negative stereotypes and assert their authentic and local credentials, they buy into and reinforce cynical assumptions about the political class. Such an insight helps to make new sense of a long-standing conundrum in political science survey research - that citizens typically express a deep dislike for elected representatives in general while approving of their own representative in particular. Politicians are desperate to develop the same relationship that Fenno identified more than three decades ago. Indeed, to generate personal trust they perpetuate collective disaffection.

Lesson 2: Coping mechanisms reinforce distance 
If the public typically disapproves of politicians - their motivations and intentionsthen they equally resent what politicians do. The presumption - echoed in rationalactor models that predominate in mainstream political science-is that their actions serve to gather and maintain their own power, and that they are willing to deceive the public in pursuit of these aims. Yet present-day ethnographic research complicates this picture. We look at two recent British studies focused on Whitehall (Rhodes 2011) and Westminster (Crewe 2015).

Rhodes's study of Ministerial life at Westminster combines hit-and-run observation and ethnographic interviewing. His account focuses on the 'departmental court' - the many actors and practices that surround the Minster to coordinate the work and manage the conflicts and relationships that characterise this work. He describes the court as a complex coping mechanism - a cocoon from the pressures of media scrutiny, political rivalries and policy surprises and failures. Permanent Secretaries and Ministers as living in a small, claustrophobic world. Their combination of a genuine need for confidentiality, a siege mentality, and habitual caution can reinforce the walls of a closed world impervious both to the diversity of opinion outside the cocoon and to the consequences of its actions for other people.

Emma Crewe's (2015) ethnographic study of the House of Commons draws together a wealth of observation, interviews and media coverage. Central to her account is a depiction of the vast array of demands facing legislators. These demands call for different sorts of social performances and can accentuate the perception of politicians as excessively partisan. On the one hand, she details the intensive relationship MPs have with their constituents. This 'glorified social work' is hidden to the external observers until they see the everyday life of a parliamentary office. Crewe observed 
that MPs, even those in safe electorate seats, tended to meet those who were not on the electoral register, who faced losing their job, or were dealing with their emotionally complex and difficult problems. The notion that MPs can simply act as the singular 'voice' of constituents, then, is confounded by the reality that most of the interactions they have with constituents are about 'fixing' their problems. On the other hand, Crewe's (2015: 153-4) work also focuses on the demands MPs face in developing, defending and scrutinizing complex policy. She shows that MPs do not, and cannot, learn extensively about all the areas they are asked to learn. Instead, the competing demands mean they have to learn 'riffs' - 90-second linguistic devices, 'perhaps seven or eight at any one time', on a topic that they have had to learn about quickly. Riffs are a form of 'message discipline'. They perpetuate the 'spin' accusations often included in explanations of democratic disaffection.

Rhodes and Crewe provide an insight into how the practices that constitute political institutions shape actions that are widely recognised to explain democratic disaffection. Crewe shows professionalization as a product of taxing constituency work, as well as an incredibly demanding and diverse policy brief. Rhodes details the 'cocoon' ministers create, and their attendant practices, as coping mechanisms against an intrusive media. These insights show the everyday institutional effects that lead to professionalization, and help us understand why politicians might often act in ways that fuel democratic disafection.

\section{Lesson 3: From Incompetence to Impotence}

The final popular charge thrown at political elites is that they lack competency. A substantial line of enquiry focuses on the failings of political elites in running 
government. (e.g. Dunleavy 1995; Bovens and t' Hart 1996; Schuck 2015). Once again, ethnographic research enables a more nuanced explanation of how 'incompetence' comes about, in this case due to unrealistic expectations.

Grant Reeher's (2006) biographical account of legislative life represents a rich collective portrait. Reeher's account draws together ethnographic interviews with dozens of state legislators across the US. In relating their intimate experiences, Reeher's account introduces a peculiar paradox of life at the top - that those who hold power often feel powerless. In his account, legislators reflect that the demands of office, and the complex political environment that they have to navigate, can leave them feeling helpless. Reeher's participants express deep frustration about the barriers that thwart their efforts towards meaningful change.

Corbett (2015) sought to replicate Reheer's study but in a different context: the Pacific Islands. He draws mainly on over 100 interviews with politicians and more than 50 auto/biographies. Corbett's account details the depth of concern about the corruption and incompetence of contemporary politicians in this region. Unflattering comparisons were made with the so-called Golden Generation who had led most Pacific states to independence in the 1970s and 1980s. The politicians at the centre of Corbett's story are complicit in reinforcing this narrative of decline. To win support, they make grand promises to improve the quality of governance and enhance living standards. Once in office, they experience first hand the inevitable powerlessness of running a weak state apparatus in a context of poverty and aid dependency.

Reeher and Corbett's insights into the feelings of powerlessness among legislators helps to explain why they often appear 'incompetent'. This time, however, the focus is not on campaigning but on the practices of governing. After building up public 
expectations to gain trust during elections, then politicians are thrown into a world of stretched resources and impossible timescales. Paradoxically, they confront now the opposite goals of managing expectations and downsizing. Again, the beliefs and practices that politicians inherit shapes the way they act, and provides nuance to our explanation of why they seem incompetent.

\section{Conclusion}

In this article, we have reviewed and reinterpreted several seminal ethnographic studies of political elites by drawing out the lessons they provide those scholars interested in public disaffection towards politics and political institutions. We draw three significant conclusions:

1) The drivers of professionalization in political campaigns lie not only in the national party system but also in local practices for building local identity to create trust and foster political ambition.

2) The coping strategies used by politicians create a 'cocoon' against hostile interest groups and media, and increase the distance between elites and citizens.

3) The incompetence of politicians stems from the paradox between the practices of campaigning and of governing, between building up expectations to win elections and reducing expectations when in office. 
Combined, these findings show how attempts by politicians to overcome some of the inherent paradoxes of democratic government adopt professionalized practices commonly assumed to fuel democratic disaffection.

For the sake of clarity and brevity, our critical review has focused on studies of elected officials. Yet, we can equally point to affinities in ethnographic research focused on the broader cast of elites engaged in contemporary governance. Given the popular disaffection with the EU, for example, Shore's (2000) account of the inner workings of the European Commission foreshadows Rhodes' portrayal of a cocooned civil service. Affinities are also clear in studies of the elite of global governance. Echoing Crewe's nuanced account of political spin, Weaver's (2008) ethnographic study of the World Bank shows how organised hypocrisy is central to the Bank's work. Moreover, like Reeher's account of powerless politicians, Ouroussof's (2010) ethnography of Wall Street elites reveals how these supposedly omnipotent kingpins of the global economy remain enthralled to limiting beliefs and entrenched practices. In each case, the lesson is the same - getting 'inside' the world of elites provides a more nuanced diagnosis of the pathologies that pervade contemporary systems of governance and feed widespread public disaffection.

So, we repeat our call for political scientists to become ethnographic bricoleurs. We do not claim it is the only approach, but rather argue that our ability to explain political phenomena is severely limited by ethnography's marginal standing in political science. Intuitively, we believe most members of the profession would be sympathetic to the view that we should collect and use different forms of data to draw on the strengths (and overcome the endemic weaknesses) of each approach. Ethnography produces descriptions characterised by detailed specificity in context 
that can form the basis of 'plausible conjectures' (Boudon 1993) and challenge the generalisations of other research traditions. It adds texture, depth, nuance and authenticity to our accounts of government as well unearthing surprises (and see Rhodes 2017: chapter 3 and 4; and Schatz 2009: chapters 1 and 14 for a discussion of the pros and cons of ethnography).

We conclude, however, by suggesting that elite ethnography might be an especially important approach given the renewed public debate about—and insurgent challenge to - the political establishment. We have pointed to the affinity between rising democratic disaffection and the entrenchment of rational actor models of governing elites in political science. This is not to assert a causal link between political science orthodoxy and public attitudes. We suggest only that elite ethnography, and the human and humanizing stories it can tell about elites, can provide a powerful alternative that might at least broaden the boundaries of public debate. 


\section{References}

Agar, M. and MacDonald, J. (1995) 'Focus Groups and Ethnography.' Human Organization, 54, 78-86.

Allen, N. and Birch, S. (2015). Ethics and Integrity in British Politics: How Citizens Judge Their Politicians Conduct and why it Matters. Cambridge: Cambridge University Press.

Allen, P, and P Cairney (2015). 'What Do We Mean When We Talk About the "Political Class"?' Political Studies Review 15 (1): 18-27

Aronoff, M. J. and Kubik, J. (2013). Anthropology and Political Science. A Convergent Approach, New York: Berghahn Books.

Atkinson, P., Coffey, A., Delamont, S., Lofland, J. and Lofland, L. (Eds.) (2001). Handbook of Ethnography, London: Sage

Auyero, J., and Joseph, L. (2007). 'Introduction: Politics under the Ethnographic Microscope', in L. Mahler, J. M. \& Auyero, J. (Eds.) New Perspectives on Political Ethnography. New York: Springer, pp. 1-13.

Bevir, M. and Rhodes R. A. W. (2003) Interpreting British Governancel London: Routledge.

Bevir, M. and Rhodes R. A. W. (Eds.) (2015). The Routledge Handbook of Interpretive Political Science. Abingdon, Oxon: Routledge.

Bevir, M. (2006). 'How Narratives Explain', in Yanow, D. and Schwartz-Shea, P. (Eds.) Interpretation and Method: Empirical Research Methods and the Interpretive Turn. Armonk, NY: M.E. Sharpe, pp. 281-90.

Boswell, J, and J Corbett (2015). 'Stoic Democrats? Anti-politics, Élite Cynicism and the Policy Process', Journal of European Public Policy 22.10: 1388-1405

Boudon, R. (1993). 'Towards a Synthetic Theory of Rationality', International Studies in the Philosophy of Science, 7: 5-19.

Bovens, Mark and Paul 't Hart. (1996). Understanding Policy Fiascos. London: Transaction.

Campbell, R, and P Cowley (2014). 'Rich Man, Poor Man, Politician Man: Wealth effects in a candidate biography survey experiment." The British Journal of Politics and International Relations 16.1: 56-74

Campbell, R. and Cowley P. (2015). 'Attitudes to Moonlighting Politicians: evidence from the UK'. Journal of Experimental Political Science. 2:1: 63-72.

Catterberg, G., and Moreno, A. (2006). 'The Individual Bases of Political Trust: Trends in New and Established Democracies.' International Journal of Public Opinion Research 18 (1): 31-48. 
Clarke, N., Jennings, W., Moss, J. and Stoker, G. (2016). The Rise of Anti-Politics in Britain. Southampton: University of Southampton.

Corbett, J. (2015). Being Political. Leadership and Democracy in the Pacific Islands. Honolulu: University of Hawai'i Press.

Cramer, K. J. (2016). The politics of resentment: Rural consciousness in Wisconsin and the rise of Scott Walker. University of Chicago Press.

Crewe, E. (2005). Lords of Parliament. Manchester: Manchester University Press.

Crewe, E. (2015). The House of Commons. London: Bloomsbury.

Crozier, M., Huntington, S. P., and Watanuki, J. (1975). The Crisis of Democracy. New York: New York University Press.

Dalton, R. J. (2004). Democratic Challenges, Democratic Choices: The Erosion of Political Support in Advanced Industrial Democracies. Oxford: Oxford University Press.

Delamont, Sara. (2007). 'Ethnography and Participant Observation', in Clive Seale, Gobo Giampietri, Jaber F. Gubrium and David S. Silverman (Eds.) Qualitative Research Practice, Thousand Oaks, CA: Sage: 205-27.

Denzin, N. K. and Lincoln, Y. S. (2011) [1994]. 'Introduction: the Discipline and Practice of Qualitative Research', in N. K. Denzin, and Y. S. Lincoln (Eds.) Handbook of Qualitative Research, 4th edition, London: Sage, pp. 1-19.

Dunleavy, P. (1995). 'Policy Disasters' Public Policy and Administration 10 (2): 52-70.

Fenno, R. F. (1978). Home Style: House Members in their Districts, Boston: Little, Brown.

Fenno, R. F. (1990). Watching politicians: Essays on participant observation. University of California.

Finifter, A W. (1970). 'Dimensions of Political Alienation.' American Political Science Review 64(2): 389-410.

Flinders, M. (2012). Defending Politics: Why Democracy Matters in the Twenty-First Century. Oxford: Oxford University Press.

Gaddie, Ronald Keith (2003). Born To Run: Origins of the Political Career. Rowman and Littlefield Publishers.

Gerring, J. (2007). Case Study Research: Principles and Practices. Cambridge: Cambridge University Press.

Geertz, C. (1993) [1973]. 'Thick Description: Toward an Interpretive Theory of Culture', in his The Interpretation of Cultures, London: Fontana, 3-30.

Glaser; Barney G. and Strauss, Anselm L. (2017) [1967)].The Discovery of Grounded Theory. Strategies for Qualitative Research. London: Routledge 
Goffman, E. (1990) [1959]. The Presentation of Self in Everyday Life. London: Penguin Books. Hammersley, M. and Atkinson, P. (2007) [1983]. Ethnography: Principles in Practice. Third edition. London: Routledge.

Hay, C. (2007). Why We Hate Politics. Cambridge: Polity.

Hetherington, Marc. (2006). Why Trust Matters: Declining Political Trust and the Demise of American Liberalism. Princeton: Princeton University Press.

Hetherington, Marc, and Rudolph, Thomas. (2015). Why Washington Won't Work: Polarization, Political Trust, and the Governing Crisis Chicago: University of Chicago Press.

Holmes, D. R. and Marcus, G. E. (2005). 'Refunctioning Ethnography: The Challenge of an Anthropology of the Contemporary', in N. K. Denzin, and Y. S. Lincoln (Eds.) Handbook of Qualitative Research, 3rd edition, London: Sage: 1087-101.

Hochschild, A. (2016). Strangers in Their Own Land: Anger and Mourning on the American Right. New York: The New Press.

Inglehart, R. and Norris, P. (2016). Trump, Brexit, and the Rise of Populism: Economic Have-Nots and Cultural Backlash, July 29. HKS Working Paper No. RWP16-026.

Auyero, J., and Joseph, L. (2007). 'Introduction: Politics under the Ethnographic Microscope', in L. Mahler, J. M. \& Auyero, J. (Eds.) New Perspectives on Political Ethnography. New York: Springer, pp. 1-13.

zewski, D., MacLean, L. M. and Read, B. L. (2015). Field Research in Political Science. Cambridge: Cambridge University Press.

Katz, J. (2001). 'From How to Why: On Luminous Description and Causal Inference in Ethnography (Part I)'. Ethnography, 2: 443-473.

Katz, J. (2002). 'From How to Why: On Luminous Description and Causal Inference in Ethnography (Part 2)'. Ethnography, 3: 63-90.

Laitin D. (2006). 'Ethnography and/or Rational Choice: a Response from David Laitin'. Qualitative Methods 4: 26-33

Maynard-Moody, S. and Musheno, M. (2003). Cops, Teachers, Counsellors: Stories from the Front Lines of Public Service. Ann Arbor, Michigan: The University of Michigan Press.

Marcus, George E. (1995). 'Ethnography in/of the World System: the Emergence of Multi-Sited Ethnography', Annual Review in Anthropology, 24: 95-117.

Marcus, George E. (2007a) 'Ethnography Two Decades after Writing Culture: From the Experimental to the Baroque', Anthropological Quarterly 80 (4): 1127-1145

Marcus, George E. (2007b). 'How Short can Field Research Be? Social Anthropology 15 (3):353-367. 
Mudde, C. (2004) 'The Populist Zeitgeist', Government and Opposition, 39 (4): 542563.

Mudde, C. (2007). Populist Radical Right Parties in Europe. Cambridge: Cambridge University Press.

Norris, P. (2005). Radical Right: Voters and Parties in the Electoral Market. Cambridge: Cambridge University Press.

Norris, P. (2011). Democratic Deficit: Critical Citizens Revisited. Cambridge: Cambridge University Press.

Oakeshott, M. (1996). The Politics of Faith and the Politics of Scepticism. Edited by Timothy Fuller. New Haven: Yale University Press.

Olsen, Marvin. (1969). 'Two Categories of Political Alienation.' Social Forces 47 (3): 288-299.

Ouroussof, A. (2010). Wall Street at War: The Secret Struggle for the Global Economy. Cambridge: Polity Press.

Pachirat, Timothy (2011). Every Twelve Seconds: Industrialized Slaughter and the Politics of Sight. Yale University Press,.

Papadopoulos, Y (2013). Democracy in Crisis. Basingstoke: Palgrave Macmillan.

Pharr, S. J., and Putnam, R. (Eds.) (2000). Disaffected Democracies: What's Troubling the Trilateral Countries? Princeton: Princeton University Press.

Pink, Sarah (2013) Doing Visual Ethnography, $3^{\text {rd }}$ edition. London: Sage

Reeher, G. (2006) First Person Political. New York: New York University Press.

Rhodes, R. A. W. (2011) Everyday Life in British Government Oxford: Oxford University Press.

Rhodes, R. A. W. and A Tiernan (2014) Lessons of Governing: A Profile of Prime Ministers' Chiefs Of Staff, Melbourne: Melbourne University Press.

Richards, D., and Mathers, H. (2010). 'Political Memoirs and New Labour: Interpretations of Power and the "Club Rules". The British Journal of Politics and International Relations, 12 (4), 498-522.

Rooduijn, M., de Lange, S. L., and van der Brug, W. (2014). 'A Populist Zeitgeist? Programmatic Contagion by Populist Parties in Western Europe'. Party Politics, 20: 563-575.

Schatz, Edward (2009). 'Introduction', in Schatz, Edward (Ed.) Political Ethnography: The Difference Immersion Makes Toronto: University of Toronto Press.: 1-22. 
Schwartz-Shea, P. and Yanow, D. (2012). Interpretive Research Design: Concepts and Processes. London: Routledge.

Schuck, P H. (2015). Why Government Fails So Often. Princeton, NJ: Princeton University Press.

Shore, C. (2000). Building Europe: The cultural politics of European integration. London: Routledge.

Shore, C. and Nugent, S. (2002). Elite Cultures. Anthropological Perspectives, ASA Monographs 38, London: Routledge.

Small, M. L. (2009). 'How Many Cases Do I Need? On Science and the Logic of Case Selection in Field-Based Research’ Ethnography 10: 5-38.

Smith, M. and Hay, C. (2015). 'Horses for Courses?' West European Politics, 28: 124158.

Stoker, G. (2006) Why Politics Matters. Basingstoke: Palgrave Macmillan.

Stoker, G., and Hay, C. (2017). Understanding and Challenging Populist Negativity towards Politics: the Perspectives of British citizens. Political Studies,65: 4-23.

Taylor, L. (2014). 'On the Endangered Art of Ethnography', Times Higher Education, 19 June: $1-5$.

Torcal, M., and Montero, J. R. (Eds.). (2006). Political Disaffection in Contemporary Democracies: Social Capital, Institutions and Politics. London: Routledge.

Weaver, C. (2009). Hypocrisy Trap: The World Bank and the Poverty of Reform. Princeton, NJ: Princeton University Press.

Wedeen, L. (2010). 'Reflections on ethnographic work in political science.' Annual Review of Political Science, 13: 255-272.

Whyte, W. F. (1993) [1943]. Street Corner Society. $4^{\text {th }}$ edition. Chicago: Chicago University Press.

Wolcott, H. F. (1995). The Art of Fieldwork. Walnut Creek, CA: Altamira Press.Wood, Elizabeth J. (2007). 'Field Research' in Carles Boix and Susan C. Stokes (Eds.), The Oxford Handbook of Comparative Politics Oxford: Oxford University Press 123-46. 
Table 1: Bricolage

\begin{tabular}{|c|c|c|c|}
\hline $\begin{array}{l}\text { Ethnographic } \\
\text { methods }\end{array}$ & Definition & $\begin{array}{l}\text { Potential data } \\
\text { sources }\end{array}$ & Model \\
\hline $\begin{array}{l}\text { Hit-and-run } \\
\text { fieldwork }\end{array}$ & $\begin{array}{l}\text { Repeated, short } \\
\text { bursts of intensive } \\
\text { observation as } \\
\text { researchers move } \\
\text { in-and-out of the } \\
\text { field }\end{array}$ & $\begin{array}{l}\text { Legislatures, } \\
\text { constituency } \\
\text { offices, campaign } \\
\text { events }\end{array}$ & $\begin{array}{l}\text { Rhodes's (2011) } \\
\text { Everyday Life in } \\
\text { British Government; } \\
\text { Crewe's (2015) The } \\
\text { House of Commons }\end{array}$ \\
\hline $\begin{array}{l}\text { Ethnographic } \\
\text { interviewing }\end{array}$ & $\begin{array}{l}\text { Repeated, semi- } \\
\text { structured and } \\
\text { unstructured } \\
\text { interviews with the } \\
\text { same participant }\end{array}$ & $\begin{array}{l}\text { Recently retired } \\
\text { politicians and } \\
\text { public officials }\end{array}$ & $\begin{array}{l}\text { Reeher's (2006) First } \\
\text { Person Political }\end{array}$ \\
\hline Memoirs & $\begin{array}{l}\text { First-person } \\
\text { reflections on } \\
\text { governing }\end{array}$ & $\begin{array}{l}\text { Auto-biographies } \\
\text { and authorized } \\
\text { biographies; radio } \\
\text { and television } \\
\text { interviews }\end{array}$ & $\begin{array}{l}\text { Richards and } \\
\text { Mathers' (2010) } \\
\text { Political Memoirs } \\
\text { and New Labour; } \\
\text { Corbett's (2015) } \\
\text { Being Political }\end{array}$ \\
\hline $\begin{array}{l}\text { Elite focus } \\
\text { groups }\end{array}$ & $\begin{array}{l}\text { Group reflections } \\
\text { that encourage } \\
\text { elites to flesh out } \\
\text { and challenge each } \\
\text { other's claims }\end{array}$ & $\begin{array}{l}\text { Recently retired } \\
\text { politicians and } \\
\text { public officials }\end{array}$ & $\begin{array}{l}\text { Rhodes and Tiernan's } \\
\text { (2014) Lessons of } \\
\text { Governing }\end{array}$ \\
\hline $\begin{array}{l}\text { Para- } \\
\text { ethnography }\end{array}$ & $\begin{array}{l}\text { An ethnographic } \\
\text { interview focused } \\
\text { around explaining a } \\
\text { particular document } \\
\text { or artefact (see } \\
\text { Holmes and Markus } \\
\text { 2005) }\end{array}$ & $\begin{array}{l}\text { Focused on } \\
\text { particular } \\
\text { legislative } \\
\text { documents, } \\
\text { departmental files }\end{array}$ & $\begin{array}{l}\text { Novel in political } \\
\text { science }\end{array}$ \\
\hline $\begin{array}{l}\text { Visual } \\
\text { ethnography }\end{array}$ & $\begin{array}{l}\text { Using video } \\
\text { recordings as a } \\
\text { form of remote } \\
\text { observation (see } \\
\text { Pink 2013) }\end{array}$ & $\begin{array}{l}\text { C-SPAN (and } \\
\text { similar footage } \\
\text { elsewhere); press } \\
\text { conferences, } \\
\text { parliament live }\end{array}$ & $\begin{array}{l}\text { Novel in political } \\
\text { science }\end{array}$ \\
\hline
\end{tabular}


Table 2: Lessons about professionalization from ethnographic research

\begin{tabular}{|c|c|c|c|}
\hline & $\begin{array}{l}\text { Assumption within } \\
\text { existing literature }\end{array}$ & $\begin{array}{l}\text { Explanation } \\
\text { derived from elite } \\
\text { ethnography }\end{array}$ & $\begin{array}{l}\text { Implication for } \\
\text { explaining } \\
\text { politicians' } \\
\text { negative political } \\
\text { behaviour through } \\
\text { everyday norms }\end{array}$ \\
\hline Campaigning & $\begin{array}{l}\text { Beltway } \\
\text { Governing elites are } \\
\text { enthralled to party } \\
\text { machinery for their } \\
\text { own career } \\
\text { ambitions. }\end{array}$ & $\begin{array}{l}\text { Home Style } \\
\text { Those seeking } \\
\text { election are at pains } \\
\text { to distance } \\
\text { themselves from the } \\
\text { central political elite } \\
\text { and adopt a localised } \\
\text { 'home style' instead. } \\
\text { E.g. Fenno } 1978, \\
\text { Gaddie } 2003\end{array}$ & $\begin{array}{l}\text { Constituency- and } \\
\text { party-based election } \\
\text { campaigns set up a } \\
\text { distinction between } \\
\text { the local and } \\
\text { national that } \\
\text { politicians play with } \\
\text { to get elected }\end{array}$ \\
\hline Representing & $\begin{array}{l}\text { Partisanship } \\
\text { Elected } \\
\text { representatives are } \\
\text { too partisan, failing } \\
\text { to represent the } \\
\text { substantive concerns } \\
\text { of their constituents. }\end{array}$ & $\begin{array}{l}\text { Coping } \\
\text { Governing elites } \\
\text { have to wear many } \\
\text { 'masks', have their } \\
\text { time and attention } \\
\text { stretched, often } \\
\text { insulate themselves } \\
\text { with experts and } \\
\text { advisers. } \\
\text { E.g. Crewe } 2005 \text {, } \\
\text { Rhodes } 2011\end{array}$ & $\begin{array}{l}\text { Mediatized } \\
\text { parliamentary } \\
\text { politics, and a lack } \\
\text { of practical } \\
\text { resources } \\
\text { incentivise } \\
\text { politicians to devise } \\
\text { 'short-cuts' that } \\
\text { reinforce partisan } \\
\text { framing }\end{array}$ \\
\hline Governing & $\begin{array}{l}\text { Incompetence } \\
\text { Democratic leaders } \\
\text { are not competent to } \\
\text { deliver on their } \\
\text { plans and promises. }\end{array}$ & $\begin{array}{l}\text { Impotence } \\
\text { The complex } \\
\text { realities of governing } \\
\text { make delivering } \\
\text { anything difficult. } \\
\text { E.g. Reeher } 2006 \text {, } \\
\text { Corbett } 2015\end{array}$ & $\begin{array}{l}\text { The norms of } \\
\text { competitive } \\
\text { electoral processes } \\
\text { require politicians } \\
\text { to make promises, } \\
\text { which build } \\
\text { expectations that } \\
\text { are subsequently } \\
\text { dashed by the } \\
\text { complexities of } \\
\text { government }\end{array}$ \\
\hline
\end{tabular}




\section{Note}

${ }^{1}$ This article is written by political scientists for political scientists and published in a political science journal, hence the focus on the disciplines of political science and (political) anthropology. Of course, we recognise that ethnography is a major approach in sociology but for sheer lack of space we leave out the large methodological literature on ethnography in sociology apart from the occasional reference. Also, we recognise that there are many alternatives to our preferred interpretive approach.

Irrespective of discipline, everyone employing ethnography owes a major debt to the Chicago School and Whyte's (1993 [1943] famous study of Street Corner Society. Any reader wishing to explore sociology and ethnography can start with Atkinson et al. (2001) and Hammersley and Atkinson (2007) [1983]. However, all is not well with ethnography in sociology. Taylor (2014) argues ethnography is 'endangered' because it takes a long time, is ethically sensitive, difficult to fund, and does not fit well with the performance assessment regime in UK universities. The irony is not lost on us that we argue for an approach that is out of favour in its heartland.

The relevant theoretical perspectives can include constructivism, cultural studies, ethnomethodology, feminism, governmentality, hermeneutics, Marxism, phenomenology, pragmatism, and psychoanalysis. For a brief review, see: Denzin and Lincoln (2011) [1994]: Part II; and Bevir and Rhodes (2015): Part II. For any reader unpersuaded by our interpretive approach, their search for an alternative could begin with Glaser and Strauss (2017) [1967)] on grounded theory, and Goffman (1999) [1956] on symbolic interactionism. 